\title{
ONGOING COMPRESSION ACROSS INTRAPLATE SOUTH AMERICA: OBSERVATIONS AND SOME IMPLICATIONS FOR PETROLEUM EXPLOITATION AND EXPLORATION
}

\section{CLÁUDIO COELHO DE LIMA ${ }^{1}$}

\begin{abstract}
Stress data compilations, intraplate stress field numerical models and space-based geodetic results show that the South American plate is now in horizontal compression and shortening. Plate wide deformation related to the Andean tectonics has been put in evidence by analyses of integrated visualizations of plate-scale information on tectonics, continental geology, topography/bathymetry, seismicity, stresses, active deformation, residual isostatic anomalies, fission track analyses, and seismically derived Moho depths and P and S wave velocity anomalies. Here, a few results of these analyses are presented and some implications of the ongoing compression for petroleum exploitation and exploration are discussed. A conceptual model for the plate-wide deformation is presented. The model states that in response to the compression, the lithosphere as a whole (or only the crust if thermal gradients are high enough) tends to buckle. The resulting antiforms are responsible for uplift along erosional borders of the basins, whereas the resulting synforms are sites of continental sedimentation, at basin centers. The denudation of sedimentary covers promotes the exhumation of increasingly deeper rocks and the adiabatic decompression, facilitating fusion and hence the observed Upper Cretaceous and Tertiary alkali-magmatism. The basement low topography adjacent to the retreating scarps is frequently associated with large Neogene basins (e.g. the Pantanal). The tendency to buckle is controlled by the previous lithospheric/crustal structure. The perception of ongoing compression opens up new perspectives for petroleum exploitation and exploration. The knowledge of the stress field is crucial for secondary recovery, hydraulic fracturing, fracture reservoir characterization and well design. About $82 \%$ of the total reserves are found along the actively deforming border between the South American and the Caribbean plates. The most important intraplate accumulations (about 5\% of the total reserves) are found in the Southeastern Brazilian margin, which has been deformed the most with respect to other margins during the Cenozoic, and continues to be the most seismically active. These facts suggest that the actual role of the active tectonics on the petroleum accumulation patterns may have been underestimated.
\end{abstract}

Keywords: South American plate, active tectonics, compression, shortening, lithospheric buckling, stress, geodesy, petroleum, exploration, exploitation.

INTRODUCTION The South American plate (SAP) is now in horizontal compression and shortening. This is shown by stress data compilations (Assumpção 1998, 1992; Ferreira et al. 1998; Lima et al. 1997); intraplate stress field numerical models (Coblentz and Richardson 1996; Meijer 1995) and space-based geodetic results (Lima 1999). All but one the available base lines from the French DORIS geodetic space-based system are shortening. Base lines that cross the Andes towards the midplate are shortening 13-20 mm/a and midplate shortening reaches $7 \mathrm{~mm} / \mathrm{a}$ over the Brazilian craton (L. Soudarin, CNES, Toulouse, written communication, 1998). Geodetic results have also confirmed that the Andean belt is still moving eastwards, thrusting the Brazilian craton (Norabuena et al. 1998). Cenozoic deformation is continent-wide spread (Cobbold et al. 1996; Lima 1999). Analyses of leak-off and hydraulic fracturing data indicate that the maximum principal stress is horizontal for most Brazilian basins (Lima Neto 1998, 1999; Lima Neto and Beneduzi 1998). The compression/shortening is probably due to the interactions between the SAP and the neighboring plates as well as with the asthenosphere (Lima 1999).

Plate-wide deformation related to the Andean tectonics has been put in evidence by analyses of integrated visualizations of available plate-scale information on tectonics, continental geology, topography/ bathymetry, seismicity, stresses, active deformation, residual isostatic anomalies, fission track analyses, and seismically derived Moho depths and P and S wave velocity anomalies (Lima 1999). Here, we firstly present a few results of the analyses of composite images and transects of plate topography and bathymetry, geology, gravity, and seismicity made by Lima (1999), which put in evidence a number of observations related to the ongoing compression/shortening. Secondly, we discuss some implications of the ongoing compression for petroleum exploitation and exploration.

\section{SOME STRUCTURAL AND TOPOGRAPHIC} EXPRESSIONS RELATED TO THE ONGOING COMPRESSION The Euler equator of the Neogene convergence between the SAP and the Nazca plates bisects the Andean topography and the underlying slab (Gephart 1994). This equator is roughly coincident with a chain of positive isostatic anomalies crossing the plate, from the Central Andes to NE-Brazil (Fig. 1). This chain concentrates seismicity and is the major plate divide, delimiting two different geotectonic, gravity and topographic domains (Fig. 2, Fig. 3 , transect 1). Implication is that strong mechanical links exist between the convergence, the Andean tectonics and the intraplate deformation (Lima 1999). Moreover, it is implicit that the plate-wide deformation is strongly dependent on older Precambrian structures, namely on a major Neoproterozoic suture (Brito Neves 1991).

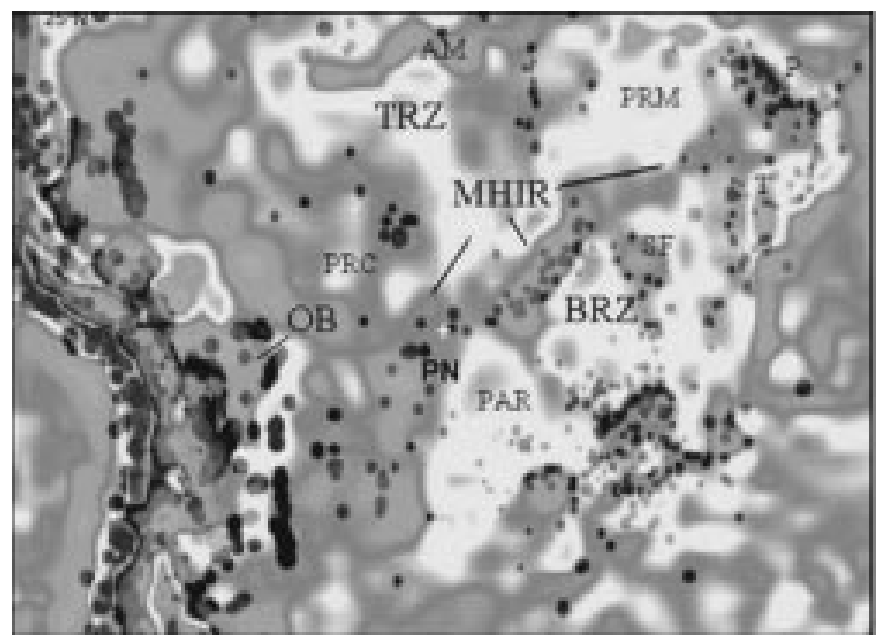

Figure 1-Overlay of isostatic residual anomalies (Ussami et al. 1993) and seismicity (dots) in South America. Negative anomalies are shown in light gray levels, positive anomalies in dark gray levels. Note the transcontinental chain of isostatic positive anomalies associated with seismicity (MHIR) crossing the plate from the Andean foreland (Pantanal basin-PN) towards the NE continental edge of the plate (the Potiguar basin, P, MesozoicTertiary), separating the midplate in two domains (Brito Neves 1991): the Brasiliano (BRZ; 450-700 Ma) and Transamazonico (TRZ; 2000 Ma). AM, the Amazon basin (Paleozoic-Tertiary), OB, Bolivian Orocline (the Central Andes salient): PAR, the Paraná basin (Paleozoic-Tertiary); $P N$, the Pantanal basin (Neogene); PRM, the Pará-Maranhão basin (Paleozoic-Tertiary); SF, the São Francisco basin (Mesozoic-Tertiary); T, the Recôncavo-Tucano basins Mesozoic-Tertiary. The location of the figure is shown by the rectangle area in Fig. 2. Modified from Lima (1999).

In front of the Central Andes salient, the western edge of the Brazilian craton has been uplifted along a line that mimics the structural lines of the Andean chain (Fig. 2). This surface uplift is due to a flexural bulge induced by vertical and horizontal loads associated with the dynamics of the chain (Shiraiwa and Ussami 1993). In response to the uplift, denudation of Tertiary and older sedimentary cover has been taking place, producing sedimentary scarps that retreat towards the Brazilian craton, exhuming the Precambrian shield and producing large areas of Neogene sedimentation like the large Pantanal basin (Fig. 2 and 3, transect 2). Seismological data available for the 


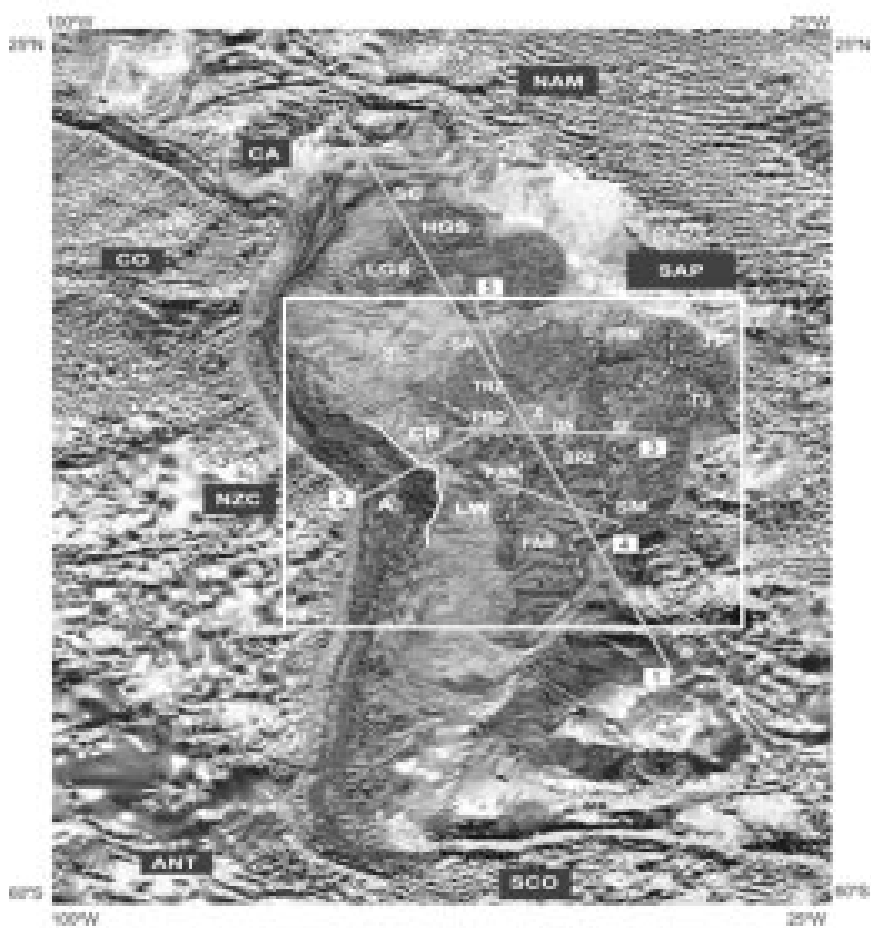

Figure 2-Geology and Topography of South America. Overlay of a shaded DTM (Digital Terrain Model) of the topography and bathymetry and the Geological Map of South America (UNESCO, 1981; original scale 1:10,000,000; sheets 4 and 5). The shaded image was built using the DTM3 database, compiled by the Leeds University in a regular grid of 3 minutes of arc. Dashed lines indicate retreating scarps formed by erosional edges of sedimentary basins. A, Andes; ANT, Antarctica Plate; BA, Amazon basin; BN, Bananal basin(Neogene); BRZ, Brasiliano domain; $C A$, Caribbean Plate; $C B$ Brazilian Craton: $\mathrm{CO}$, Cocos Plate; HGS, Highlands of the Guyana shield; LGS, Lowlands of the Guyana shield; NAM, North America Plate; NZC, Nazca Plate; PAN, Pantanal basin(Neogene); PAR, Paraná basin; PO, Potiguar basin; PRC, Parecis basin; PRM, Pará-Maranhão basin; $S$ Solimões basin; SAP, South America Plate; SC, South Caribbean Fold Belt; SCO, Scotia Plate; SF, São Francisco basin; SM, Southeastern Brazilian Coastal Ranges; TRZ, Transamazonico domain; TU, Recôncavo-Tucano basins; X, Xingu basin. Transect 1-5 are shown in Fig. 3. Modified from Lima (1999).

Paraná basin to the east of the Pantanal, indicate that the Moho is depressed under the center of the basin (where there is a thin belt of Neogenic sedimentation) and raised towards its erosional borders (Assumpção et al. 1997). These observations suggest a continentalscale lithospheric deformation comprising an antiform at the Pantanal and a synform at the Paraná basin. Moreover, this deformation is, at least in part, related to the Andean tectonics (Fig. 4).

Similar processes relating seismicity, gravity anomalies and retreating of sedimentary scarps seem to be operating at different scales in all continental basins, including isolated Tertiary covers deposited over crystalline basement (Fig. 3). All these basins are actually remnants of basins, whose erosional edges are associated with positive isostatic anomalies, and frequently with seismicity. They are in incipient inversion (Ziegler 1989); their borders are being uplifted and eroded, whereas their axes, along with major river flows (e.g. the Paraná and the Amazon) are subsiding, being sites of a narrow belt of Neogene sedimentation. Along the raised borders, Cretaceous and Devonian marine sediments may be found several hundred of meters high. The same marine sediments have been found by drilling, several hundred of meters-deep at the centers of the basins. As a result of the scarp retreating process, the sedimentary cover is stripped and Precambrian crystalline rocks are exhumed adjacent to basins. Therefore, in those areas, basement systematically outcrops at lower topographic levels, and is, in some places, associated with large Neogene basins.

A CONCEPTUAL MODEL FOR THE OBSERVED WIDESCALE INTRAPLATE DEFORMATION In order to explain this scenario Lima (1999) proposed that, in response to the
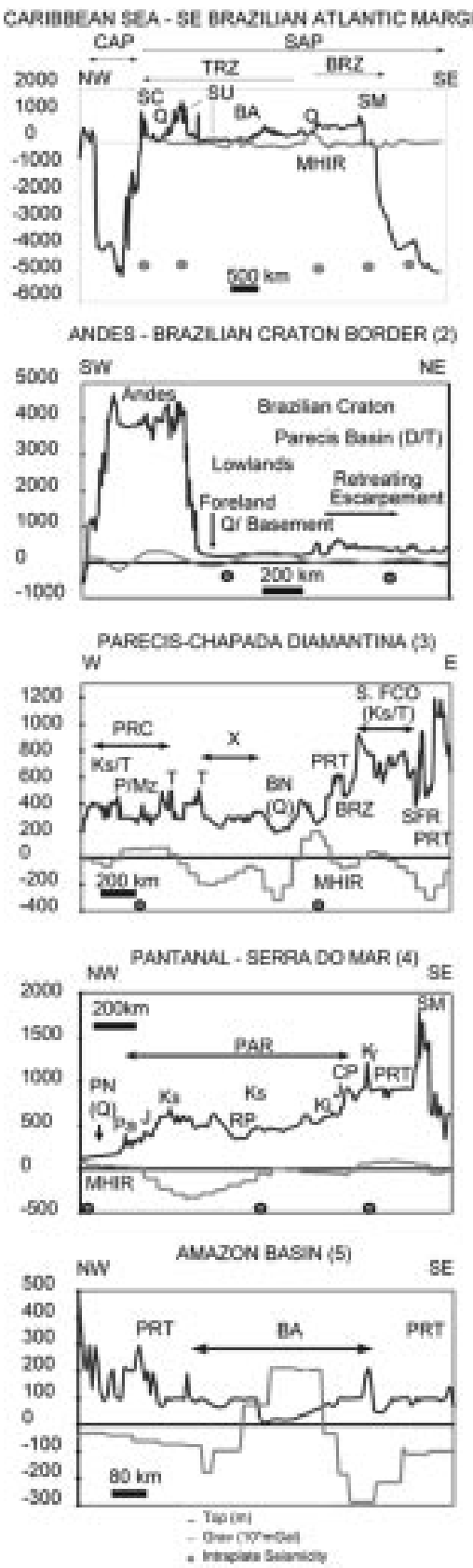

Figure 3-Transects comparing topography, isostatic anomalies, geology and seismicity. Transect 1. The transcontinental chain of positive anomalies $(M H I R)$ is associated in surface with low topography and Neogene sedimentation $(Q)$. This chain separates the plate in two topographic, geotectonic and gravity domains. In the Tranzamazonico domain high topography is found near to the contact between the Caribbean plate (CAP) and the South American plate (SAP). Transects 2-5. The erosional borders of the basins in incipient inversion outcrop at higher topographic levels than the adjacent basement. At the base of the retreating sedimentary scarps, the basement areas are frequently associated with active Neogene sedimentation. The borders of the sedimentary basins are associated with positive isostatic anomalies and frequently with seismicity. Double arrows indicate the remnants of sedimentary basins along the transect. Note the systematic anticorrelation between denudation and topography. The most denuded areas are topographic lows frequently associated with seismicity and Neogene sedimentation. BA, Amazon basin (mostly Paleozoic); BN (Q), Bananal basin (Neogene); BRZ, Brasiliano domain; C, Carboniferous; CAP, Caribbean Plate; HGS, Highlands of the Guyana Shield; J, Jurassic; Ki, Lower Cretaceous (tholeiitic basalts); K(g) Upper Cretaceous alkaline volcanic rocks; Ks, Upper Cretaceous; LGS, Lowlands of the Guyana Shield; Mz Mesozoic; P, Permian; Pa, Paleozoic; PAR, Paraná basin (mostly Paleozoic); $P N(Q)$, Pantanal basin (Neogene); PRT, Proterozoic; Q, Quaternary/ Neogene; RP. Paraná River; SAP, South America Plate; SC, Caribbean Fold Belt; SFR, S. Francisco River; SM, Southeastern Brazilian Coastal Ranges; SU, Uatumã Supergroup; T, Tertiary; TRZ, Tranzamazonico domain; TU, Tucano Recôncavo Jatobá basins. Modified from Lima (1999). 
compression, the lithosphere as a whole (or only the crust if thermal gradients are high enough) tends to buckle (Fig. 4).

The resulting antiforms are responsible for uplift along basin erosional borders, whereas the resulting synforms are sites of continental sedimentation, at basin centers. In fact, during the Upper Cretaceous, continental sediments, whose remnants are $250 \mathrm{~m}$-thick, were deposited along the axis of the Paraná basin (Milani 1997). This sedimentation is concomitant with the Upper Cretaceous Peruvian orogenesis. The advection of mantle materials towards the forming antiforms, together with denudation, promotes adiabatic decompression, facilitating fusion, and hence, the observed Upper Cretaceous and Tertiary alkalic magmatism. This tendency was stronger during peaks of the Andean orogenesis. The denudation of sedimentary covers promotes the exhumation of increasingly deeper rocks, which outcrop at the foot of retreating scarps. Consequently, the erosional borders of the basins form local high topography with respect to the adjacent basement. The basement low topography is frequently associated with large Neogene basins (e.g. the Pantanal). Seismicity, always associated with positive residual isostatic anomalies, is concentrated about inflection points between forming synforms and antiforms, along the erosional borders of basins, probably absorbing most of the shortening. The high topography of SE Brazilian Coastal Range, supposedly associated with a lithospheric antiform, could be explained by the compressional interaction of the continental lithosphere with the very strong oceanic lithosphere found eastwards. This is consistent with the observed compressional deformation found at the transitional limit between both lithospheres (Bassetto 1997). The tendency to buckle is controlled by preexisting lithospheric/crustal structure.

This conceptual model has been numerically tested and the preliminary results were successful in replicating the main aspects of the observed ongoing deformation of cratonic South America, namely the anticorrelation between lithospheric structure and topography and the concentration of seismicity about the inflexion points of the lithospheric/crustal folding, i. e. the raised erosional borders of the sedimentary basins (Lima et al.1999) (Figs. 4 and 5).

\section{SOME IMPLICATIONS OF ONGOING COMPRESSION} FOR PETROLEUM EXPLOITATION AND EXPLORATION

The knowledge of the stress field is crucial for secondary recovery, conventional horizontal/directional drilling and hydraulic fracturing (Bell 1990). Numerical simulations are currently used in the petroleum industry to plan well design in order to prevent stability problems.

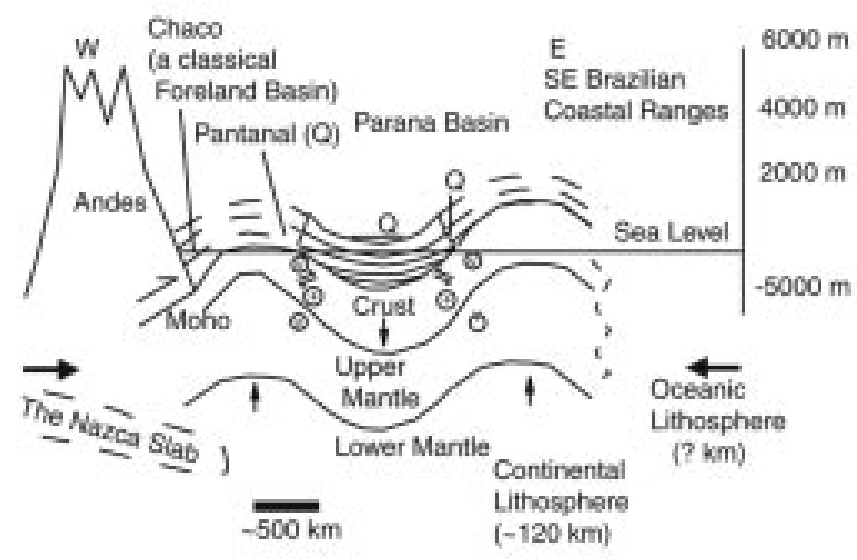

Q. Upper Cretacecus
Alkaline Rocks
O Seismicty
Q. Active Neogene
Sedimentation

Figure 4-Conceptual model for lithospheric deformation along a schematic transect between the Central Andes and the SE Brazilian Atlantic Margin (Lima 1999). See text for explanation

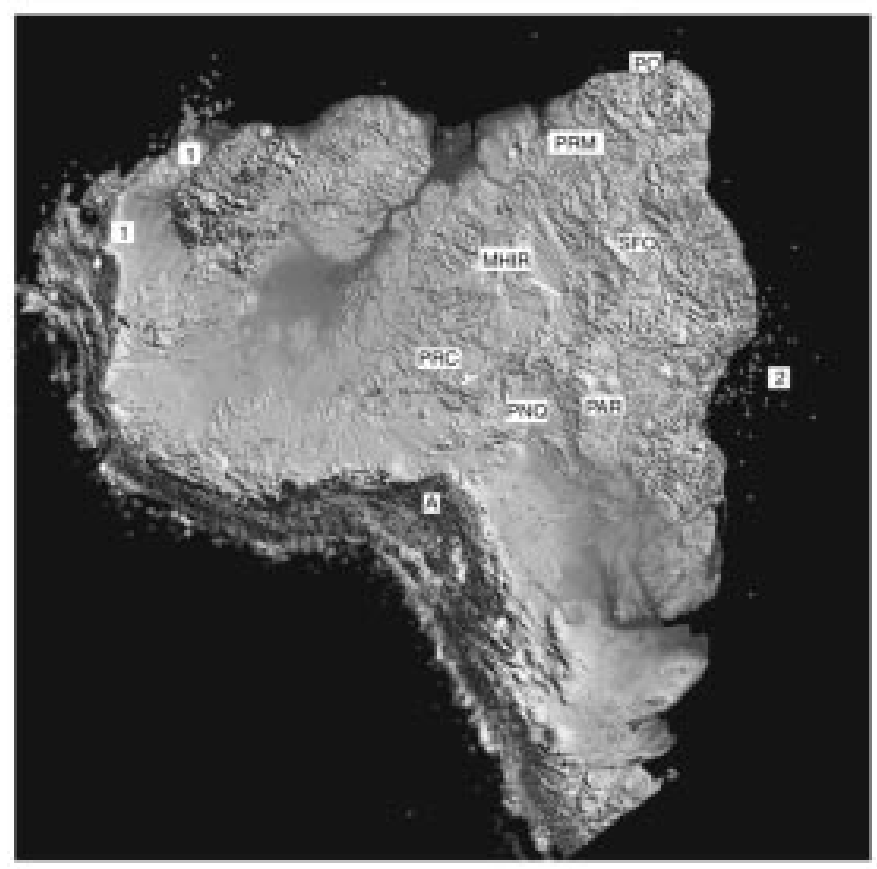

Figure 5-3-D Visualization of South American topography, seismicity and denudation patterns. The digital model of the topography was built with the TOPO 30 data set downloaded from the USGS website (delivered with a resolution of 30 seconds arc). Dots and circles are epicenters. The Pantanal $(P N Q)$ is a Neogene basin associated with a lithospheric antiform, whereas the Paraná basin (PAR) overlies a lithospheric synform. Continental seismicity is predominantly found along denuded areas associated with positive isostatic anomalies (MHIR) where basin sediments have been stripped. A, Central Andes; basin remnants: Potiguar (PO), Parecis (PRC), Para-Maranhão (PRM) and São-Franciscana (SFO); 1 and 2, major South American petroleum accumulations. See discussion on the text and next figure. Image processing by Cristina Bentz (PETROBRAS/CENPES). Modified from Lima et al. (1999).

Feeding numerical simulators with actual stress values avoids inaccurate assumptions, such as the statement that passive margins are "relaxed", and helps anticipating solving stability problems.

It has been shown for 80 petroleum fields throughout the world that a strong positive correlation exists between permeability anisotropy and the maximum horizontal stress (SHmax) (Heffer and Lean 1991). This correlation stands for fracture as well as for conventional reservoir and has been also observed in laboratory experiments (Bruno et al. 1991). Consistently, the importance of taking into account insitu stresses in fracture reservoir characterization has been increasingly recognized and incorporated to reservoir modeling during the last years (e.g. Ameen 1999; Batchelor 1999).

Accumulations are ephemeral in a geologic time scale, being strongly dependent on seals fine geometry and biodegradation. The perception of the ongoing compression, and its inherent potential for modifying trapping structures, could probably help to understand details of the trapping itself.

One of the most important conditions for the formation of petroleum accumulations is the occurrence of good source rocks that are now, or have been until recently, within the oil generation window (Perrodon 1995). This is the case for source rocks of the most important Subandean and intraplate South American petroleum systems, whose peaks of expulsion are found in the Neogeone, and even in the Present (Mello et al. 1997; Mello et al. 1994). Given the positive correlation between SHmax and permeability anisotropy (e.g. Heffer and Lean 1991), I infer that the neotectonic stress field could have an important role on the secondary migration.

According to Price (1994), the tectonic disruption of the source rock should be the most important mechanism controlling primary migration. To test his hypothesis, Price (1994) compared basin richness (ratio between recoverable reserves and basin area) and intensity of tectonism for 70 basins throughout the world. He found a direct correlation between these two parameters, the end members being the cratonic basins, the poorest and the less structured; the 
Tertiary wrench basins being the richest and the most structured. He also concluded that anomalous higher richness in cratonic or passive margin basins are mostly associated with an anomalous structuring.

This seems to be the case for the most important South American provinces. About $82 \%$ of the total reserves (the third most important ones on a global scale) are found along the actively deforming border between South-American and Caribbean plates. Indeed, the most important intraplate accumulations (about 5\% of the total reserves) are found in the Southeastern Brazilian margin (the Campos basin), which has been deformed the most with respect to other margins during the Cenozoic, and continues to be the most seismically active (Fig. 6; Lima 1999).

DISCUSSION AND CONCLUSIONS Assuming an elastic rheology, early studies of lithosphere flexure showed that, for reasonable levels of compressional forces, the induced vertical displacements of the lithosphere are negligible. Combined with the lack of evidence from natural examples this led until recently to the withdrawal of attention from lithospheric folding (Cloetingh 1992).

Meanwhile, during the last two decades, several studies concerning numerical and analogue modeling based on other rheologies (viscousplastic and elasto-plastic) have been developed. In addition, natural examples of lithospheric folding have been recognized in both oceanic and in continental domains (Davy and Cobbold 1988; Martinod and Davy 1992, 1994; Beekmann 1994).

By combining tectonics with available plate-scale information on stresses, geodesy, seismology, topography, geology, gravity and geomorphology, Lima (1999) presented a compelling example for large-scale lithospheric buckling and incipient compressional reactivation of tensional basins. Once again, 2-D numerical modeling was successful in qualitatively replicating the observed deformation (Lima et al. 1999).

The concepts that firstly passive margins are "relaxed" (submitted only to minor normal faults) and secondly that the formation of structures have been terminated a long time ago, are deeply seated within the oil industry. The perception that intraplate South America basins (and, probably, basins of other intraplate areas also) are under compression and are actively being deformed is opposed to these two concepts and opens up new perspectives for exploitation and exploration strategies. Namely, this perception strongly suggests that the actual role of the active tectonics on the petroleum accumulation patterns may have been underestimated.

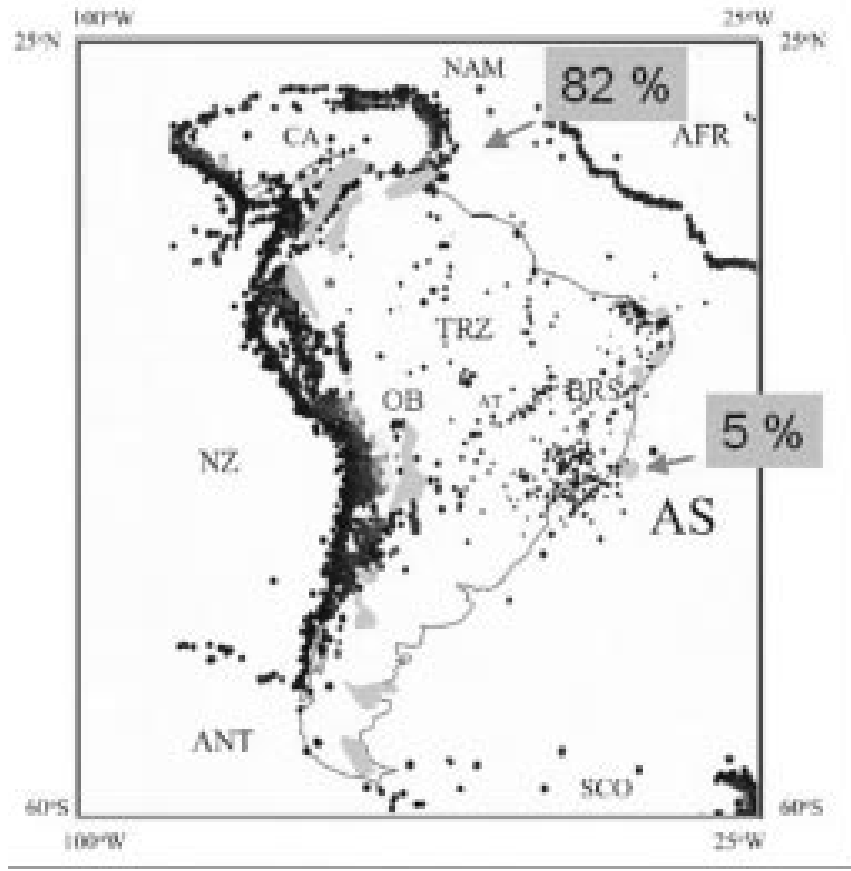

Figure6-Active tectonics and petroleum provinces in South America. Dots are epicenters; in the Andean salient (Bolivian Orocline, OB). Areas in gray are petroleum provinces. All South American petroleum provinces are found along actively deforming borders or in intraplate areas associated with moderate seismicity. About $82 \%$ of the total are found along the border between South American and Caribbean plates whereas $5 \%$ are found in the Southeastern Brazilian margin, which has been deformed the most with respect to other margins during the Cenozoic and continues to be the most seismically active. AFR, AS, and ANT are the African, South American, Antarctica plates. BRS and TRZ are the Brasiliano and the Transamazonico domains. AT is the transcontinental belt of intraplate seismicity associated with positive isostatic anomalies crossing the plate from the Central Andes to NE Brazil

\section{References}

Ameen M. 1999. Characterization of directional permeability zones for production and development purposes: a case study from a mature field, Saudi Arabia. In: Fracture \& In-situ Stress Characterization of Hydrocarbon Reservoir, London, Geological Society (Abstract Volume).

Assumpção M. 1998. Seismicity and stress in the Brazilian passive margin. Bulletin of the Seismological Society of America, 88 (1):160-169.

Assumpção M. 1992. The regional intraplate stress field in South America. Journal of Geophysical Research, 97:11889-11903.

Assumpção M., James D., Snoke A. 1997. Crustal Thickness in SE Brazilian Shield with Receiver Function: Isostatic Compensation by Density Variations in the Lithospheric Mantle? In: International Congress of the Brazilian Geophysical Society, 5, Expanded Abstracts, 895-897.

Basseto M. 1997. Análise morfo-estrutural do domínio oceânico da porção sul-sudeste da margem continental brasileira. MSc. Thesis, Universidade Federal de Ouro Preto, Minas Gerais, Brazil, $147 \mathrm{p}$

Batchelor T. 1999. In situ stresses: a key control on fracture permeability and reservoir pressure. In: Fracture \& In-situ Stress Characterization of Hydrocarbon Reservoir, London, Geological Society (Abstract Volume).

Beekman F. 1994. Tectonic modeling of thick-skinned compressional intraplate deformation. Ph. D. Thesis, Vrije Universiteit, The Netherlands, $151 \mathrm{p}$

Bell J.S. 1990. Investigating stress regimes in sedimentary basins using information from oil industry wire line logs and drilling records. In: A. Hurst, M.A. Lowell, A.C. Morton (eds), Geological Applications of Wireline Logs. Geological Society Special Publication, 48:305-325.

Brito Neves B.B. 1991. Os dois Brasis geotectônicos. Atas do XIV Simpósio de Geologia do Nordeste, 6-8.

Bruno M.S., Bovberg C.A. \& Nakagawa F.M. 1991. Anisotropic stress influence on the permeability of weakly-cemented sandstones. Rock Mechanics as Multidisciplinary Science, Balkema, Rotterdam, 375-383.

Cobbold P.R., Szatmari P., Lima C.C \& Rosselo E.A. 1996. Cenozoic Deformation Across South America: Continent - Wide Data and Analogue Models. In: ISAG, 3, St Malo, France, Abstract Volume, 21-24.

Coblentz D.D. \& Richardson R.M. 1996. Analysis of the South American intraplate stress field. Journal of Geophysical Research, 101:8643-8657.
Cloetingh S. 1992. Intraplate stress and sedimentary evolution. In: G.C. Brown, C.J. Hawkesworth, R.C.L. Wilson (eds), Understanding the Earth: a new synthesis. Cambridge University Press, 415-434.

Davy, P. \& Cobbold, P.R. 1988. Indentation tectonics in nature and experiment, 1. Experiments scaled for gravity. Bulletin of the Geological Institute, University of Uppsala, N.S., 14:129-141.

Davy P. \& Cobbold P.R. 1991. Experiments on shortening of a 4-layer model of the continental lithosphere. Tectonophysics, 188:1-25.

Ferreira J.M., Oliveira R.T., Takeya M. et al. 1998. Superposition of local and regional stresses in Northeast Brazil: evidence from focal mechanisms around the Potiguar marginal basin. Geophysical Journal International, 134:341 - 355.

Gephart J.W. 1994. Topography and subduction geometry in the central Andes: clues to the mechanics of a noncollisional orogen. Journal of Geophysical Research, 99:1227912288.

Heffer K.J. \& Lean J.C. 1991. Earth stress orientation - a control on, and guide to flooding directionality in a majority of reservoirs. In: B. Linville (ed.), International Reservoir Characterization Technical Conference, Tulsa / Okla, vol. III, 800 - 822.

Lima C.C. 1999. Expressions topographiques et structurales de l'état de compression généralisée au sein de plaque sud-américaine. $\mathrm{Ph}$. D. Thesis, University of Rennes 1 , France, $369 \mathrm{p}$.

Lima C.C., Nascimento E.\& Assumpção M. 1997. Stress orientations in Brazilian sedimentary basins from breakout analysis: implications for force models in the South American plate. Geophysical Journal International, 130:112-124.

Lima C.C., Amaral C., Moraes A., Da Costa A. M. 1999. Are the large wave-length South American intraplate deformation and the incipient inversion of continental Brazilian basins manifestations of ongoing lithospheric/crustal folding? In: International Congress of the Brazilian Geophysical Society, 6, Rio de Janeiro, Paper SBGf 305. (On Compact Disc. CD-ROM).

Lima Neto F.F. 1998. Um exemplo da interferência de uma interface fraca na distribuição regional de esforços tectônicos: o campo atual de tensões da bacia Potiguar, Nor deste Brasileiro. MSc Thesis, Universidade Federal de Ouro Preto (UFOP), Minas Gerais, Brazil, $320 \mathrm{p}$.

Lima Neto F.F. 1999. O regime atual de tensões nas bacias sedimentares brasileiras. In: Simpósio Nacional de Estudos Tectônicos, 7, Sessão 4, Lençóis, Brazil, Abstracts Volume, 25-28. 
Lima Neto F.F. \& Beneduzi C. 1998. Using leakoff tests and acoustic logging to estimate in situ stresses at deep waters - Campos Basin. Extended Abstracts Volume, American Association of Petroleum Geologists International Conference \& Exhibition, Rio de Janeiro, Brazil, 224-225

Martinod J. \& Davy P. 1992. Periodic instabilities during compression or extension of the lithosphere: 1. Deformation modes from an analytical perturbation method. Journal of Geophysical Research 97:1999 -2014.

Martinod J. \& Davy P. 1994. Periodic instabilities during compression of the lithosphere: 2. Analogue experiments. Journal of Geophysical Research, 99:12057-12069.

Meijer P.TH. 1995. Dynamics of active continental margins: the Andes and the Aegean region. Ph. D. Thesis, Utrecht Univ., the Netherlands.

Mello M.R., Koutsoukos E.A.M., Mohriak W.U. et al. 1994. Selected Petroleum Systems in Brazil. In: L.B. Magoon \& W.G. Dow (eds) The petroleum system - from source to trap. American Association of Petroleum Geologists, Memoir 60, Chapter 31, 499 $-512$

Mello M.R., Trindade L.A.F., Gil E., et al. 1997. Geochemical Characterization of South American Subandean Petroleum Systems. In: Simposio Bolivariano de Exploração Petrolera en las Cuencas Subandinas, Abstracts Volume, 324-336.

Milani E.J. 1997. Evolução Tectono - Estratigráfica da Bacia do Paraná e seu Relacionamento com a Geodinâmica Fanerozoica do Gondwana Sul - Ocidental. Ph. D. Thesis, Universidade Federal do Rio Grande do Sul, Brazil, 255 p.

Norabuena E., Leffler-Griffin L., Mao A. et al. 1998. Space Geodetic Observations of Nazca - South America Convergence Across the Central Andes. Science, 279:358 362 .
North F.K. 1994. Petroleum Geology. Chapman \& Hall, London, 631 p.

Perrodon A. 1995. Petroleum systems and global tectonics. Journal of Petroleum Geology, 18(4): 471 - 476

Price L.C. 1994. Basin richness and source rock disruption - a fundamental relationship? Journal of Petroleum Geology, 17(1):5 - 38

Shiraiwa S. \& Ussami N. 1993. Flexura da litosfera continental sob os Andes centrais e a origem da bacia do Pantanal. In: Congresso da Sociedade Brasileira de Geofisica, 3 , Abstracts Volume, $1096-1102$.

UNESCO 1981. Atlas géologique du monde (sheets 4 \& 5), 1:10.000.000.

Ussami N., Sá N.C., Molina E.C. 1993. Gravity map of Brazil: 2. Regional and residual isostatic anomalies and their correlation with major tectonic provinces. Journal of isostatic anomalies and their correlation
Geophysical Research, 98:2199-2208.

Ziegler P.A. 1989. Geodynamic model for Alpine intraplate compressional deformation in Western and Central Europe. In: M.A. Cooper \& G.D. Williams (eds) Inversion tectonics. Geological Society Special. Publication, 44:63-85.

Contribution IGC-198

Received March 13, 2000 Accepted for publication May 20, 2000 